\title{
Distributed glacier mass-balance modelling as an important component of modern multi-level glacier monitoring
}

\author{
Horst MACHGUTH, Frank PAUL, Martin HOELZLE, Wilfried HAEBERLI \\ Department of Geography, University of Zürich-Irchel, Winterthurerstrasse 190, CH-8057 Zürich, Switzerland \\ E-mail: machguth@geo.unizh.ch
}

\begin{abstract}
Modern concepts of worldwide glacier monitoring include numerical models for (1) interconnecting the different levels of observations (local mass balance, representative length change, glacier inventories for global coverage) and (2) extrapolations in space (coupling with climate models) and time (backward and forward). In this context, one important new tool is distributed massbalance modelling in complex mountain topography. This approach builds on simplified energy-balance models and can be applied for investigating the spatio-temporal representativity of the few massbalance measurements, for estimating balance values at the tongue of unmeasured glaciers in order to derive long-term average balance values from a great number of glaciers with known length change, and for assessing special effects such as the influence of Sahara dust falls on the albedo and mass balance or autocorrelation effects due to surface darkening of glaciers with strongly negative balances. Experience from first model runs in the Swiss Alps and from applications to the extreme conditions in summer 2003 provides evidence about the usefulness of this approach for glacier monitoring and analysis of glacier changes in high-mountain regions. The main difficulties concern the spatial variability of the input parameters (e.g. precipitation, snow cover and surface albedo) and the uncertainties in the parameterizations of the components of the energy balance. Field measurements remain essential to tie the models to real ground conditions.
\end{abstract}

\section{INTRODUCTION}

During the past few decades, rapidly increasing knowledge together with fast, if not accelerating, changes in nature have made glacier fluctuations a key element of early-detection strategies related to atmospheric warming (Houghton and others, 2001). Monitoring and modelling approaches are closely interconnected thereby: data from monitoring can be used to calibrate or validate numerical models, and numerical model simulations help to understand information from monitoring programmes and to design focused long-term observations.

The present contribution discusses distributed glacier mass-balance models and their applicability for modern glacier monitoring. A brief introduction about the role of numerical models in modern and integrated multi-level glacier monitoring is followed by a detailed description of three case studies. They focus on the integrated use of field measurements and numerical modelling and are intended to emphasize that modern glacier-monitoring strategies have to apply both techniques in a complementary sense. The critical discussion of the results obtained leads to a discussion of future possibilities and still existing difficulties to be overcome.

\section{NUMERICAL MODEL SIMULATIONS IN MODERN GLACIER-MONITORING STRATEGIES}

Observational concepts for monitoring future glacier changes include the possibility of dramatic scenarios, i.e. the complete deglaciation of entire mountain ranges within a few decades. Advanced and future-oriented concepts have been developed (Haeberli and others, 2000, 2002; Haeberli, 2004) within the framework of the Global Terrestrial Observing System (GTOS) as part of global climate-related observational programmes (Global Climate Observing System (GCOS)). They follow a tiered strategy, which leads from (1) detailed process studies (extensive energy- and mass-balance, climate and flow measurements) via (2) regional measurements of mass balance (summary results from reduced stake networks and repeated mapping, laser altimetry on large glaciers), (3) the determination of glacier length changes (samples which are representative for variable glacier geometry and individual mountain ranges) to (4) periodically repeated glacier inventories compiled by means of satellite imagery and geoinformatics using digital terrain information (cf. Haeberli and Hoelzle, 1995).

This multi-level approach includes numerical models for (1) interconnecting the different levels of observations and (2) extrapolations in space (coupling with climate models) and time (backward and forward). The cumulative length change of glaciers, for instance, is the result of all mass-/ energy-balance and flow effects combined, and constitutes the key to a global intercomparison of glacier mass losses at the decade and century timescale. Time series of balance and length measurements are now close to the estimated dynamic response times of individual glaciers (Jóhannesson and others, 1989) and make it possible to derive long-term average mass balances from cumulative length changes of the network glaciers (Haeberli and Hoelzle, 1995; Haeberli and Holzhauser, 2003). Systematic analysis of corresponding data (Hoelzle and others, 2003) shows that the reported mass-balance series are indeed representative for large areas and long time periods. Past, current and potential future developments can be studied by dynamically fitting massbalance histories to present-day geometries and historical length-change measurements of long-observed glaciers using time-dependent flow models (Oerlemans and others, 1998; Oerlemans, 2001). 


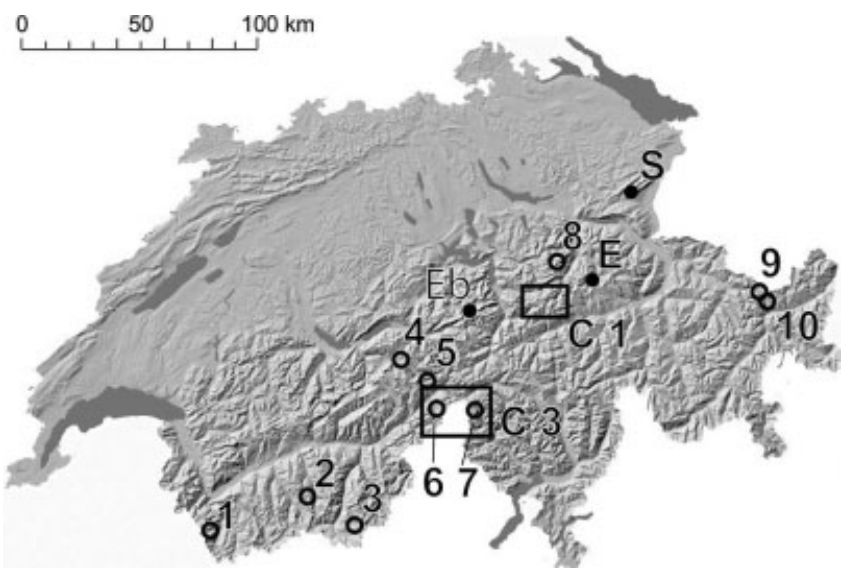

Fig. 1. Overview of the test site locations. $\mathrm{C} 1$ is test site for case study 1 . Climate stations used in case study 1 are denoted by Eb: Engelberg, E: Elm and S: Säntis. Nos. 1-10 are glaciers used in case study 2 as follows: 1 . Saleina; 2. Moiry; 3. Findel; 4. Oberer Grindelwald; 5. Oberaar; 6. Gries; 7. Basòdino; 8. Glärnisch; 9. Silvretta; 10. Tiatscha. C3 is test site for case study 3.

Application of such models leaves no doubt about the fact that many of the glaciers presently observed for mass balance could vanish within a few decades. Indeed, surface lowering, thickness loss and the resulting reduction in driving stress and flow may increasingly replace processes of tongue retreat by processes of downwasting or even collapse coupled with enhanced feedbacks from albedo and balance/ elevation effects (Paul and others, 2004). Assessing the regional representativeness of glacier mass-balance measurements by comparisons between long-term observational series of mass-balance and glacier length change could face more and more difficulties. Distributed (spatial) massbalance modelling for glaciers in complex high-mountain topography is a possible way to not only solve this problem, but also strikingly increase the time resolution of regional intercomparisons. As most glaciers with long-term massbalance measurements were selected for easy access and logistical or political reasons, distributed mass-balance models can help to assess the representativity of a specific glacier with respect to all glaciers in a larger region covering different sizes, aspects and topographic characteristics. Moreover, the intercomparison is no longer limited to the typical response time of glaciers (decades), but can be assessed on annual or even shorter time periods (e.g. winter and summer balance). In this study, we address these challenges with three case studies in the Swiss Alps which focus on the combined use of measurements and modelling utilizing modern geoinformatic techniques.

\section{CASE STUDIES}

The location of the test sites for all three case studies is illustrated in Figure 1. All three case studies make use of massbalance models using the energy-balance approach. For a comprehensive overview of energy-balance modelling with respect to glacier melt, refer to Hock (2005). Case studies 1 and 2 are based on the same simple formulation of the energy fluxes, but for the first study the model has been extended by a parameterization scheme for avalanches. In case study 3 we apply a more complex formulation of the energy balance, but the model runs without considering avalanches.
In the first case study, we use index measurements of annual snow accumulation that have been sampled at two sites (2700 and $2900 \mathrm{~m}$ a.s.I.) on Claridenfirn glacier since 1914. The data from Claridenfirn are of very good quality and were published by Müller and Kappenberger (1991), the Swiss Glaciological Commission (SCNAT, 1992) and Haeberli and others (2005). These isolated measurements lack a clear scientific concept and are difficult to integrate into modern glacier-monitoring strategies (Haeberli and others, 2000, 2005). We here test their applicability for verification of a simple distributed mass-balance model running over a 20 year period (1981-2002). The second case study derives mean specific glacier mass balance for the 1961-90 period on ten selected glaciers following an approach by Jóhannesson and others (1989) applied by Haeberli and Hoelzle (1995). In this case study, we combine measured glacier length changes with modelled ablation at the glacier tongue using the same mass-balance model as above. In the third case study, we force a distributed mass-balance model with the special meteorological conditions of the extreme summer of 2003 and compare the results to the measurements at the two mass-balance glaciers Griesgletscher and Ghiacciaio del Basòdino. The model also accounts for the specifically low 2003 glacier albedo as derived from satellite data, and for the spatial variability of precipitation from the Schwarb and others (2001) climatology.

\section{Case study 1: Claridenfirn - modelling and observations}

\section{Model description}

We use a simple mass-balance model as described by Oerlemans (2001) that is based on the calculation of the energy balance. Our version of the model is enhanced by an accurate calculation of mean daily potential global radiation using the DEM25 level 2 (a digital elevation model with $25 \mathrm{~m}$ spatial resolution from Swisstopo, representing glacier surfaces in the mid-1990s). The model runs at daily steps, and the cumulative mass balance $B_{\text {cum }}$ on day $t+1$ is calculated for every time-step and every individual gridcell as:

$$
B_{\text {cum }}(t+1)=B_{\text {cum }}(t)+\Delta t\left[\min \left(0 ;-\frac{E}{L}\right)+P_{\text {solid }}\right],
$$

where $t$ is the discrete time variable, $\Delta t$ is the time-step, $L$ is the latent heat of fusion of ice $\left(334 \mathrm{~kJ} \mathrm{~kg}^{-1}\right)$ and $P_{\text {solid }}$ is solid precipitation in metres water equivalent ( $m$ w.e.). Any meltwater is immediately removed from the glacier, and the energy available for melt $(E)$ is calculated as (see Oerlemans, 2001):

$$
E=d(1-\alpha) Q_{\mathrm{e}}+C_{0}+C_{1} T_{\mathrm{a}}
$$

where $d$ is a reduction factor for incoming shortwave radiation which accounts for cloudiness or haze, $\alpha$ is the albedo of the surface, $Q_{e}$ is the clear-sky shortwave radiation, and $C_{0}+C_{1} T_{\mathrm{a}}$ is the sum of the longwave radiation balance and the turbulent exchange linearized around the melting point $\left(T_{\mathrm{a}}\right.$ is in $\left.{ }^{\circ} \mathrm{C}\right)$. As recommended by Oerlemans (2001), $C_{1}$ was set to $10 \mathrm{~W} \mathrm{~m}^{-2}$ and we used $C_{0}$ as a tuning factor (giving best fit at $-25 \mathrm{~W} \mathrm{~m}^{-2}$ ). For every day, $d$ is calculated by dividing measured and calculated daily means of global radiation. The program operates with three different albedo values, for ice $\left(\alpha_{\mathrm{i}}=0.3\right)$, for snow $\left(\alpha_{\mathrm{s}}=0.7\right)$ and for firn $\left(\alpha_{\mathrm{f}}=0.4\right)$. At the start of the calculation the albedo is set to $\alpha_{\mathrm{i}}$ for the entire test site, and for any snow accumulation $\alpha_{\mathrm{s}}$ is used. Accumulated 


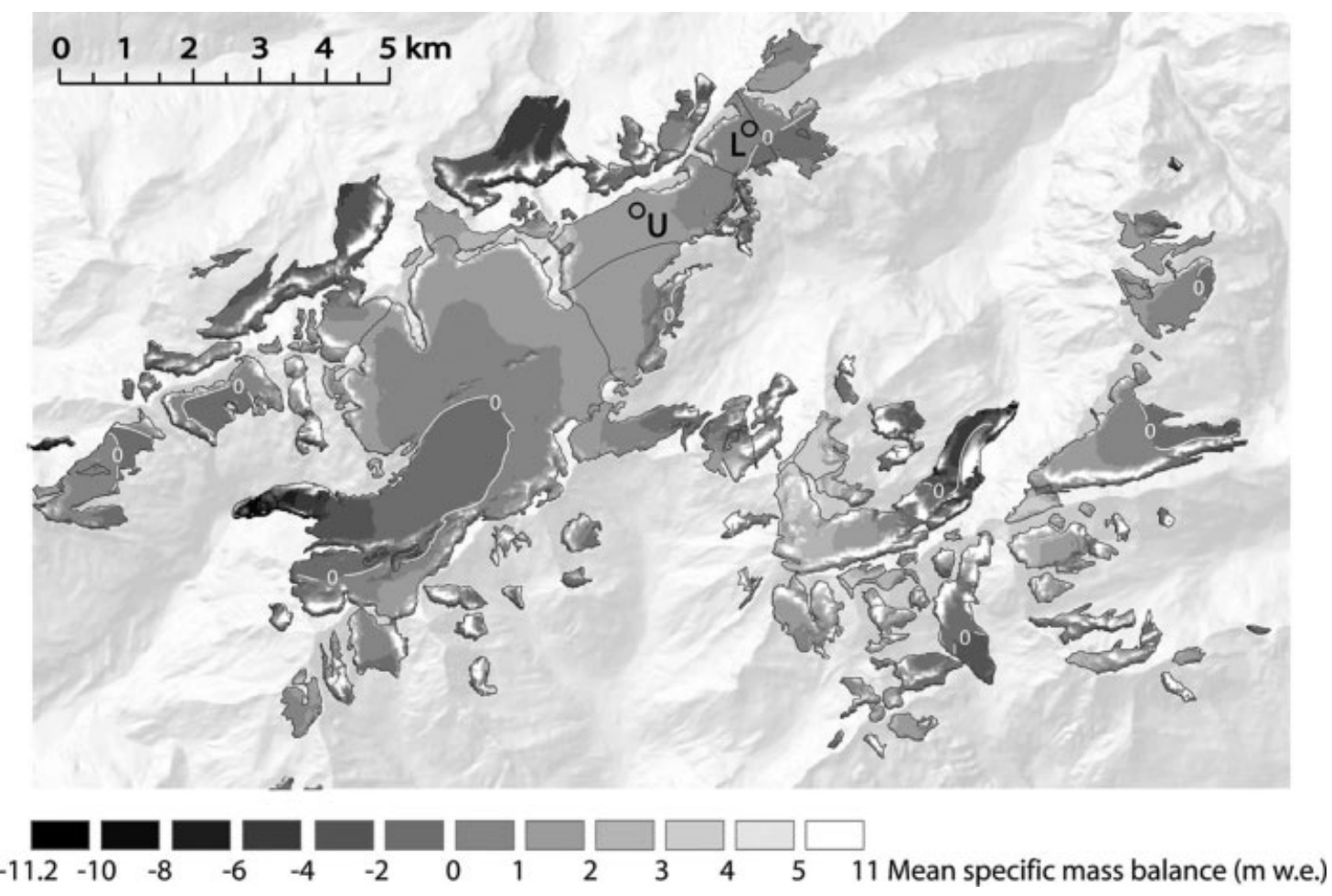

Fig. 2. Modelled mean distributed specific mass balance for all glaciers within the perimeter of test site 1 , calculated with the 20 year transient model run. Stake locations on Claridenfirn are indicated with circles ( $\mathrm{L}$ is lower stake, $\mathrm{U}$ is upper stake). In the background a shaded relief representation of the DEM25 is shown. DEM25 reproduced by permission of Swisstopo (BA057384).

snow is treated with the firn albedo $\left(\alpha=\alpha_{\mathrm{f}}\right)$ when its age exceeds 365 days and after 2 years its albedo is set to the value of ice $\left(\alpha=\alpha_{\mathrm{i}}\right)$. The mean daily potential global radiation $Q_{e}$ is calculated beforehand for all 365 Julian days from the SRAD code. This code takes into account the effects of slope, aspect and topographic shading as well as a standard atmospheric composition with a clear-sky transmissivity dependent on elevation for every individual gridcell of the respective DEM (Wilson and Gallant, 2000).

In order to improve the modelling of snow accumulation, snow redistribution by avalanches is included in the model. The parameterization scheme is based upon the multiple flow-direction algorithm developed by Quinn and others (1991) and has been adapted for avalanches by S. Gruber (personal communication, 2005). In the model, the percentage of removed snow is zero for cells with a slope of less than $30^{\circ}$ and increases linearly to $100 \%$ for cells steeper than $60^{\circ}$. First, the transport fraction from each cell to its neighbours is determined. Then, an initial array of transported snow mass is iteratively propagated along its topographically determined flow path. Finally, for cells with a slope of less than $30^{\circ}$ a deposition function describes the amount of snow deposited and removed from the propagated mass. When all snow is deposited, the model iteration is stopped. Avalanches are computed for every day when snowfall at $3000 \mathrm{~m}$ a.s.l exceeds $0.02 \mathrm{mw}$.e.; otherwise snowfall is distributed evenly.

\section{Input data}

Claridenfirn index measurements are used to verify a 20 year transient model run starting on 29 September 1981 and ending on 17 October 2002. The test site is $18 \mathrm{~km}$ by $14 \mathrm{~km}$ in size, with Claridenfirn almost in its centre, and is represented by a rectangular section of the DEM25 (Figs 1 and 2). The highest correlation between mean measured winter accumulation on Claridenfirn and average winter precipitation at climate stations nearby exists for Elm at 960 m a.s.l. (Müller and Kappenberger, 1991). However, we calculate daily precipitation for Claridenfirn from the measurements at Elm (25 km to the west) and Engelberg ( $25 \mathrm{~km}$ to the east at $1020 \mathrm{~m}$ a.s.l.) to have a spatially more homogeneous coverage. Precipitation is distributed to the terrain by means of an elevational gradient that is calculated based on Müller and Kappenberger (1991) by matching the mean winter precipitation at Elm (1959-83) with the mean winter accumulation measured at the upper stake on the glacier over the same time period. A linear regression gives a correlation coefficient of 0.77 between measured and modelled winter accumulation at the upper stake, with an underestimation of 0.17 mw.e. by the model. However, matching the precipitation measurements with glacier accumulation is not satisfying. The accumulation on the glacier does not depend only on precipitation but is the result of a complex set of variables, including snowdrift or melt events after the autumn stake readings.

Daily means of global radiation (to obtain the daily correction factor $d$ ) and temperature (using a constant lapse rate of $0.00625 \mathrm{~K} \mathrm{~m}^{-1}$ ) are acquired from the Säntis climate station (2501 ma.s.l, $55 \mathrm{~km}$ to the northeast; Fig. 1). Despite its long distance from the glacier, this high-mountain station was chosen to avoid extrapolations over large elevation intervals.

\section{Results}

The modelled 20 year mean mass-balance distribution for the entire test site is presented in Figure 2. Large bands of avalanche deposits are visible on many glaciers beneath steep mountain slopes, indicating that their dominant source 

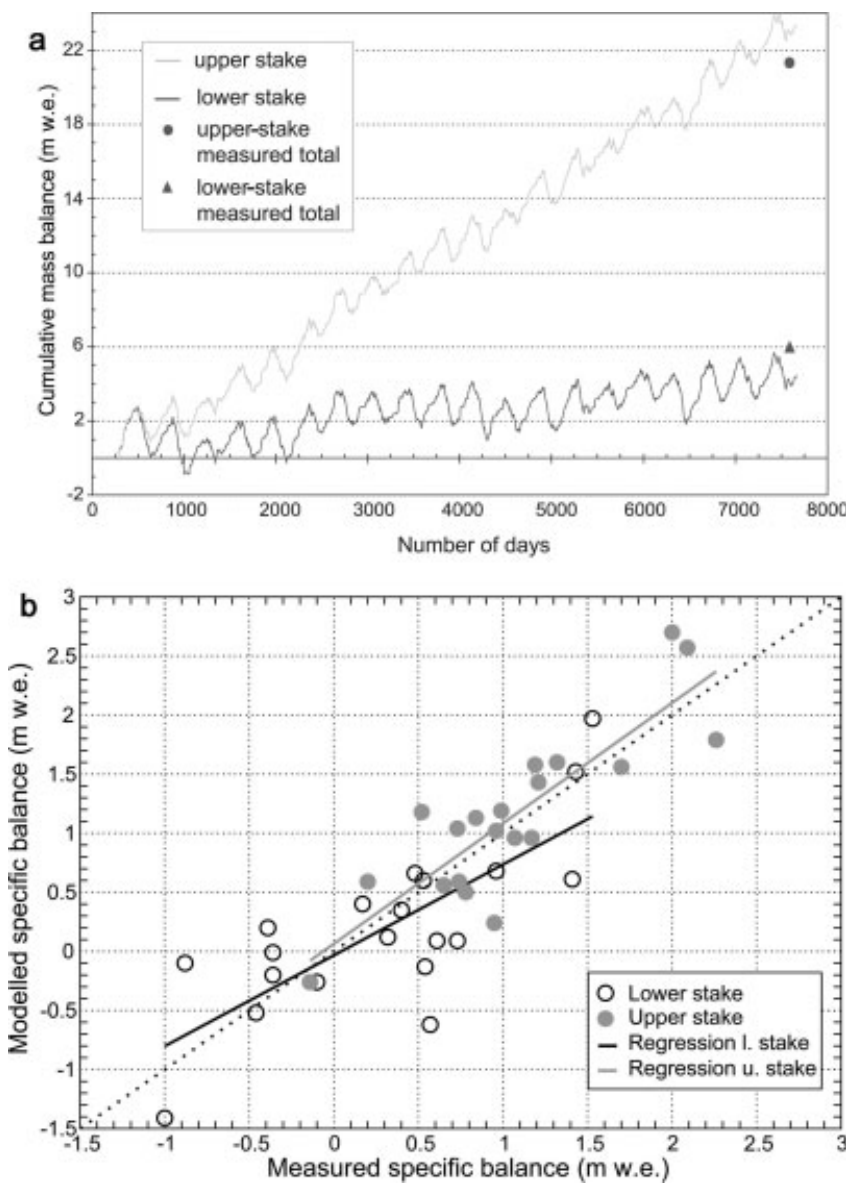

Fig. 3. (a) Cumulative mass balance for the upper and lower stakes, calculated in a 20 year transient continuous model run from 1981 to 2002. The measured cumulative mass balance is also indicated. The stakes are located well above the equilibrium line, and the measured mass gain does not represent the overall mean yearly mass loss of about $0.7 \mathrm{~m}$ w.e. observed on Alpine glaciers during the same period. (b) Scatter plot of annual measured and modelled mass-balance values with linear regression trend lines for the lower (2700 m a.s.l.) and upper (2900 m a.s.I.) stakes.

of nourishment is avalanche snow. In general, the modelled mass balances are positive for most glaciers, in contrast to the observed glacier shrinkage in this time period. In view of the simplifications made in the model (the description of the energy balance is very simple, wind redistribution of snow is not included, precipitation is only a function of altitude and cloudiness is a daily constant), the results are nevertheless promising.

To assess the accuracy of the 20 year transient continuous model run, we compare the measurements on Claridenfirn to the modelled values of the corresponding cells of the DEM25. The cumulative mass-balance curves at the positions of the two stakes are depicted in Figure 3a. The final values for both stakes are summarized in Table 1. A more detailed comparison of modelled and measured annual mass balances is depicted in the scatter plot given in Figure 3b. We obtain correlation coefficients of 0.77 for the lower and 0.86 for the upper stake. The mean yearly mass balance is underestimated by $0.09 \mathrm{~m}$ w.e. at the lower and overestimated by $0.08 \mathrm{~m}$ w.e. at the upper stake (Table 1). As stake measurements are performed at different dates with a varying time-span from year to year, the corresponding time periods are used for the modelled balances. In summary, we find that the simple
Table 1. Comparison of modelled and observed values at the two stake locations (2700 and 2900 ma.s.l) on Claridenfirn. The calculation period runs from 29 September 1981 to 17 October 2002

\begin{tabular}{lcccc}
\hline & \multicolumn{2}{c}{ Lower stake } & \multicolumn{2}{c}{ Upper stake } \\
& Modelled & Observed & Modelled & Observed \\
\hline $\begin{array}{l}\text { Cumulative balance } \\
\text { (m w.e.) }\end{array}$ & 4.3 & 6.1 & 23.0 & 21.3 \\
$\begin{array}{l}\text { Mean mass balance } \\
\text { (m w.e.) }\end{array}$ & 0.22 & 0.31 & 1.15 & 1.07 \\
$\begin{array}{l}\text { Mean winter balance } \\
\text { (m w.e.) }\end{array}$ & & & 2.11 & 2.28 \\
\hline
\end{tabular}

mass-balance model performs well in the long-term calculation for the two stakes on Claridenfirn, but on the other hand the model run results in positive (up to $+1.4 \mathrm{~m}$ w.e. on some glaciers) and consequently quite unrealistic mass balances for the neighbouring glaciers. Hence, the parameterization of avalanches is an important improvement to the model. Nevertheless, the spatio-temporal distribution of precipitation, as well as the redistribution of snow by wind, are essential to obtain a more realistic mass-balance distribution over large areas and long time-spans. Measurements have shown that even adjacent glaciers have large differences in mean accumulation. In addition, the accumulation pattern of the measured glaciers has revealed a high spatial variability (Machguth and others, 2006).

\section{Case study 2: glacier mass balance from measured length changes and modelled tongue ablation}

\section{Model description}

Curves of cumulative glacier advance and retreat can be converted into time series of temporally averaged mass balance by applying a simple continuity model originally proposed by Nye (1960). This approach considers step changes after full dynamic response and new equilibrium of the glacier. Thus, the mass-balance disturbance $(\delta b)$ leading to a corresponding glacier length change $(\delta L)$ depends on the original length $\left(L_{0}\right)$ and the annual mass balance (ablation) at the glacier terminus $\left(b_{t}\right): \delta b=b_{t} \delta L / L_{0}$. The dynamic response time $\left(\tau_{\mathrm{r}}\right)$ is $h_{\max } / b_{\mathrm{t}}$ (Jóhannesson and others, 1989), where $h_{\max }$ is a characteristic ice thickness, usually taken at the equilibrium line where ice depths are near maximum. Assuming a linear adjustment of the mass balance $b$ to zero during the dynamic response, the average mass balance $\langle b\rangle$ is roughly assumed to be $\delta b / 2$. The value so obtained is given in annual ice-thickness change ( $\mathrm{m}$ w.e.) averaged over the entire glacier surface, and can be directly compared with values measured in the field or modelled values as described in case study 1 . The main limitation is the resolution in time. Applying characteristic values for $b_{\mathrm{t}}$ and maximum thicknesses of 30 to several hundred metres, the response time is 10-100 years (Haeberli and Hoelzle, 1995). The calculated mean specific mass-balance values are therefore valid in the range of several decades to a century (Hoelzle and others, 2003).

For this case study, the mean specific mass balances are calculated for ten selected glaciers of the Swiss glaciermonitoring network according to their individual characteristic response times using the modelled values of $b_{\mathrm{t}}$ and $\mathrm{d} b$ / $\mathrm{d} h$ (Table 2). They are compared to the modelled values 
Table 2. Summary of input data (columns 2-9) used for the model, and output data (columns 10-12) calculated by the model (see case study 2), for the glaciers given in the first column

\begin{tabular}{|c|c|c|c|c|c|c|c|c|c|c|c|}
\hline Glacier & $\begin{array}{c}\max \\
\mathrm{m}\end{array}$ & $\underset{\mathrm{m}}{\mathrm{min}}$ & $\begin{array}{c}\text { ELA } \\
m\end{array}$ & $\begin{array}{l}\Delta L \\
\mathrm{~m}\end{array}$ & $\begin{array}{l}L_{0} \\
\mathrm{~km}\end{array}$ & $\begin{array}{c}\mathrm{d} b / \mathrm{d} h \\
\mathrm{~m}(100 \mathrm{~m})^{-1}\end{array}$ & $\begin{array}{c}b_{\mathrm{t}} \\
\text { mw.e. }\end{array}$ & $\begin{array}{c}\langle b\rangle \\
\text { m w.e. }\end{array}$ & $\begin{array}{l}\text { thick } \\
\mathrm{m}\end{array}$ & $\begin{array}{c}t_{\mathrm{r}} \\
\text { years }\end{array}$ & $\begin{array}{c}\left\langle b^{\prime}\right\rangle \\
\text { mw.e. }\end{array}$ \\
\hline & $\begin{array}{c}\text { A } \\
(2)\end{array}$ & $\begin{array}{c}\text { B } \\
(3)\end{array}$ & $\begin{array}{c}C \\
(4)\end{array}$ & $\begin{array}{l}D \\
(5)\end{array}$ & $\begin{array}{c}D \\
(6)\end{array}$ & $\begin{array}{c}C \\
(7)\end{array}$ & $\begin{array}{c}C \\
(8)\end{array}$ & $\begin{array}{c}C \\
(9)\end{array}$ & $\begin{array}{c}E \\
(10)\end{array}$ & $\begin{array}{c}E \\
(11)\end{array}$ & $\begin{array}{c}\mathrm{E} \\
(12)\end{array}$ \\
\hline Basòdino & 3220 & 2620 & 2860 & 54 & 1.6 & 0.65 & -1.7 & 0.01 & 80 & 47 & 0.03 \\
\hline Findel & 4200 & 2540 & 3240 & -185 & 9.48 & 0.9 & -6.2 & -0.17 & 220 & 35 & -0.06 \\
\hline Glaernisch & 2920 & 2330 & 2590 & -61 & 2.33 & 0.7 & -1.8 & -0.20 & 120 & 67 & -0.02 \\
\hline Gries & 3360 & 2450 & 2860 & -564 & 6.77 & 0.7 & -2.7 & -0.17 & 200 & 74 & -0.11 \\
\hline Moiry & 3820 & 2450 & 3090 & -150 & 5.78 & 0.63 & -4.2 & -0.13 & 200 & 48 & -0.05 \\
\hline Oberer Grindelwald & 3740 & 1500 & 2870 & 521 & 5.18 & 0.56 & -7.9 & 0.23 & 180 & 23 & 0.29 \\
\hline Oberaar & 3420 & 2320 & 2830 & -343 & 5.0 & 0.7 & -3.4 & -0.13 & 200 & 59 & -0.12 \\
\hline Saleina & 3880 & 1800 & 2920 & 183 & 6.46 & 0.64 & -7 & 0.18 & 250 & 36 & 0.10 \\
\hline Silvretta & 3160 & 2450 & 2800 & -115 & 3.46 & 0.88 & -2.65 & -0.28 & 150 & 57 & -0.04 \\
\hline Tiatscha & 3120 & 2540 & 2840 & 84 & 2.06 & 0.82 & -2.35 & 0.31 & 120 & 51 & 0.05 \\
\hline
\end{tabular}

Notes: max and min are maximum and minimum elevation, respectively, ELA is equilibrium-line altitude, $\Delta L$ is length change from 1961 to $1990, L_{0}$ is glacier length in $1961, \mathrm{~d} b / \mathrm{d} h$ is mass-balance gradient, $b_{\mathrm{t}}$ is mass balance at the tongue, $\langle b\rangle$ is modelled mean mass balance for the $1961-90$ period, thick is glacier thickness, $t_{\mathrm{r}}$ is response time and $\left\langle b^{\prime}\right\rangle$ modelled mass balance from length-change data. Data sources: A: Swiss Glacier Inventory (1973); B: topographic maps (1990); C: mass-balance model; D: Swiss Glaciological Commission (SCNAT, 1992); E: calculated.

of $\langle b\rangle$ as obtained with the same distributed mass-balance model as used in case study 1 (Machguth, 2003). In contrast to the Claridenfirn model run, climatic means of temperature (1961-90) and global radiation (1980-2000) from Meteoswiss are used as input. Seasonal precipitation means (1971-90) are obtained from Schwarb and others (2001). The uncorrected precipitation values are increased by $30 \%$. (Schwarb and others (2001) recommend a correction of their high-mountain precipitation values by $15-30 \%$.)

Table 2 shows that the calculated response times are in general longer than 30 years, except for Oberer Grindelwaldgletscher. The response times as calculated here use the $b_{\mathrm{t}}$ values determined by the mass-balance model from case study 1 . These $b_{\mathrm{t}}$ values are much lower than the values calculated in earlier studies (Haeberli and Hoelzle, 1995), mainly because of shading effects at the tongue of the glaciers that are now considered. Therefore, the resulting response times are in general too long compared to observations. The calculation of input parameters was not carried out automatically as in previous studies (Haeberli and Hoelzle, 1995; Hoelzle and Haeberli, 1995; Hoelzle and others 2003), but individually for each glacier (see input data in Table 2).

\section{Results}

Figure 4 shows a comparison between the modelled mean specific mass balances based on the length-change data and the modelled mean specific mass balances based on the mass-balance model described above (time period 196190). Although the general agreement is quite good, there are two cases where the correlation is low. The first case is Tiatschagletscher, which has a complex topography with a cascade-like icefall near the tongue. This complex structure at the tongue produces a special length-change behaviour, with a delayed reaction of the tongue during an advance period. The second case is Silvrettagletscher, which is difficult to model due to contradictory precipitation input data from Schwarb and others (2001) and from the Hydrological Atlas of Austria (BLFUW, 2003). We have to keep in mind that the simple model approach applied here has several limitations as well, and that the data should be interpreted with care. Nevertheless the results show a new possibility for mass-balance model validation in areas without direct measurements.

\section{Case study 3: distributed mass-balance modelling for Griesgletscher and Ghiacciaio del Basòdino in the extreme 2002/03 balance year}

\section{Model description and input data}

In case study 3, we apply a different distributed massbalance model which is of intermediate complexity with respect to the energy-balance formulation, and calculate the mass balance for Griesgletscher and Ghiacciaio del Basòdino (for location see Figs 1 and 5a) for the extreme summer 2003 conditions (Schär and others, 2004). Model results are compared with field measurements which are obtained by the direct glaciological method on both glaciers (Herren and others, 1999). This model, too, is based on the general approach that the most important variables for Alpine

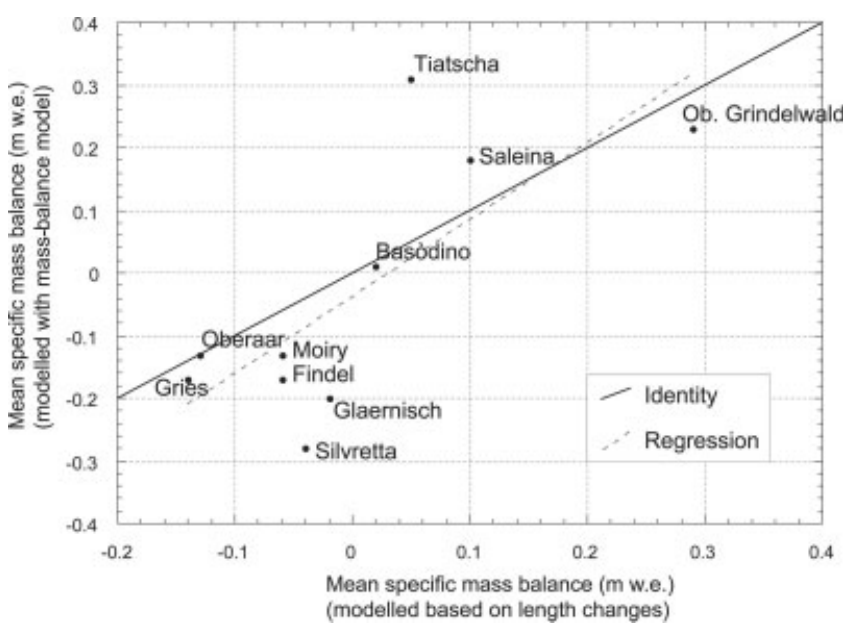

Fig. 4. Comparison between modelled specific mass balance based on the mass-balance model and modelled specific mass balance based on measured cumulative length changes for the period 196190 for ten glaciers from the Swiss glacier-monitoring network. 

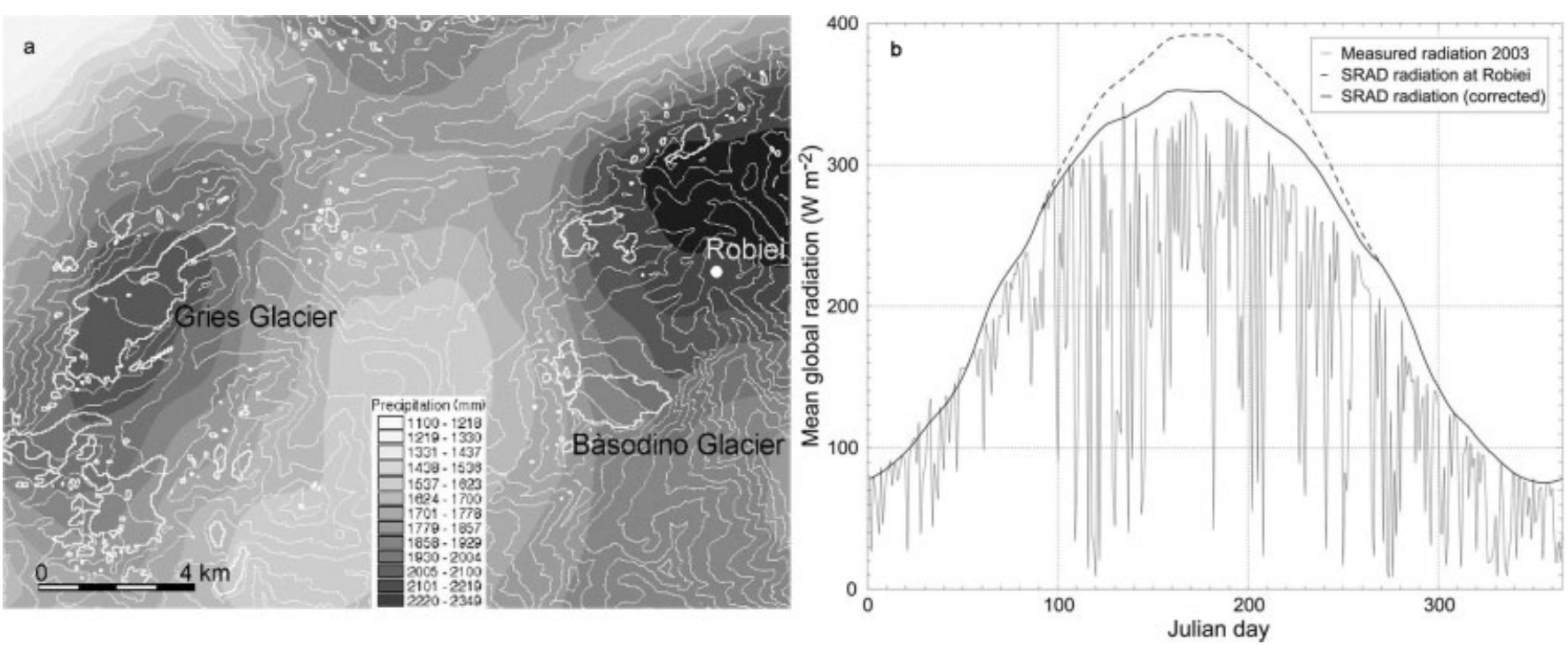

Fig. 5. (a) Annual precipitation sums for the test site from the Schwarb and others (2001) climatology (1971-90 mean values) resampled to $25 \mathrm{~m}$ cell size. Satellite-derived glacier outlines from 2003 (thick white lines) and $200 \mathrm{~m}$ elevation contours from the DEM25 (thin light grey lines) are superimposed. The filled white circle (right, centre) marks the location of the Robiei climate station at $1900 \mathrm{~m}$ a.s.l. DEM25 reproduced by permission of Swisstopo (BA057384). (b) Measured global radiation (daily means) at Robiei for 2003, together with modelled potential global radiation from SRAD at the same site before and after correction.

glacier mass balance be included with the highest possible precision (e.g. potential global radiation, albedo, precipitation pattern) while others are treated more generally or are parameterized roughly (cf. Oerlemans, 2001). The model is a combination of the formulations given by Oerlemans (1992, 1993) and Klok and Oerlemans (2002) and adapted for a forcing by meteorological input data from a climate station (temperature, precipitation, global radiation). Distribution of the input data to the terrain is performed by means of elevation-dependent gradients (using the DEM25) and gridded data fields that are calculated beforehand (Paul and others, in press). This includes high-resolution fields of climatological (1971-90 mean values) annual precipitation totals from Schwarb and others (2001), as well as a map of glacier albedo obtained from a Landsat Thematic Mapper (TM) scene acquired on 13 August 2003, utilizing a method developed by Knap and others (1999) and described in more detail in Paul and others (2005).

The total annual precipitation shows a local maximum near the Robiei climate station (1900 ma.s.I.) with decreasing values towards higher elevations (Fig. 5a). In order to retain the complex precipitation pattern observed throughout the region, we normalized the precipitation data by the value found at the location of Robiei. The daily precipitation at each cell is then obtained by multiplication of the measured precipitation at Robiei with the normalized grid and finally increasing it by $20 \%$, as proposed by Frei and Schär (1998) for elevations above 1500 ma.s.l. After a correction has been applied to the global radiation from SRAD, the cloud factor is obtained for the entire test site from the ratio of the measured to the potential global radiation at Robiei (Fig. 5b).

An albedo of 0.75 is used for freshly fallen snow (with an exponential aging curve) and TM-derived glacier albedo is used if snow depth in the model becomes zero. The model takes into account the extremely low glacier albedo values $(<0.2)$ observed at the end of summer 2003 (Paul and others,
2005). A constant value of 0.1 is added to all albedo values in order to account for effects of the non-Lambertian reflectance characteristics of ice and snow (Greuell and de Ruyter de Wildt, 1999). Some other variables required in the model (e.g. pressure, humidity) use a fixed climatologic mean value at a certain elevation and are extrapolated from the DEM25 for each pixel according to their gradients.

The model starts on Julian day 271 (1 October 2002) with zero snow depth at each cell, and calculates cumulative mass balance for each cell in daily steps until day 635 (30 September 2003) is reached. Snow redistribution by wind and avalanches is not yet included in this model, but seems to be an important factor for the modelled mass balance of many smaller glaciers (see case study 1 ). Mass balances and mass-balance profiles at $50 \mathrm{~m}$ elevation bins are obtained by Geographical Information System (GIS)based modelling, i.e. intersecting the recent (2003) satellitederived glacier perimeter (Paul and others, 2002) with the DEM25 and the obtained mass-balance distribution.

\section{Results and validation}

The modelled mass-balance distributions for Griesgletscher and Ghiacciaio del Basòdino are depicted in Figure 6a and $b$, respectively, with highlighted glacier areas and approximate positions of the ablation stakes (numbered). While mass-balance distribution on the glacier tongue is governed by the albedo pattern, the potential global radiation exerts a major influence in all other regions. In particular, regions on steep slopes which are prone to heavy topographic shading exhibit positive balances, as avalanches are not included in this model. In consequence, these regions are actually not covered by glaciers (see Fig. 6a and b). The modelled (measured) mean specific mass balances (in mw.e.) for Griesgletscher and Ghiacciaio del Basòdino in the 2002/03 balance year are: $-2.63(-2.52) /$ $-2.08(-2.04)$. These results are promising with respect to the 

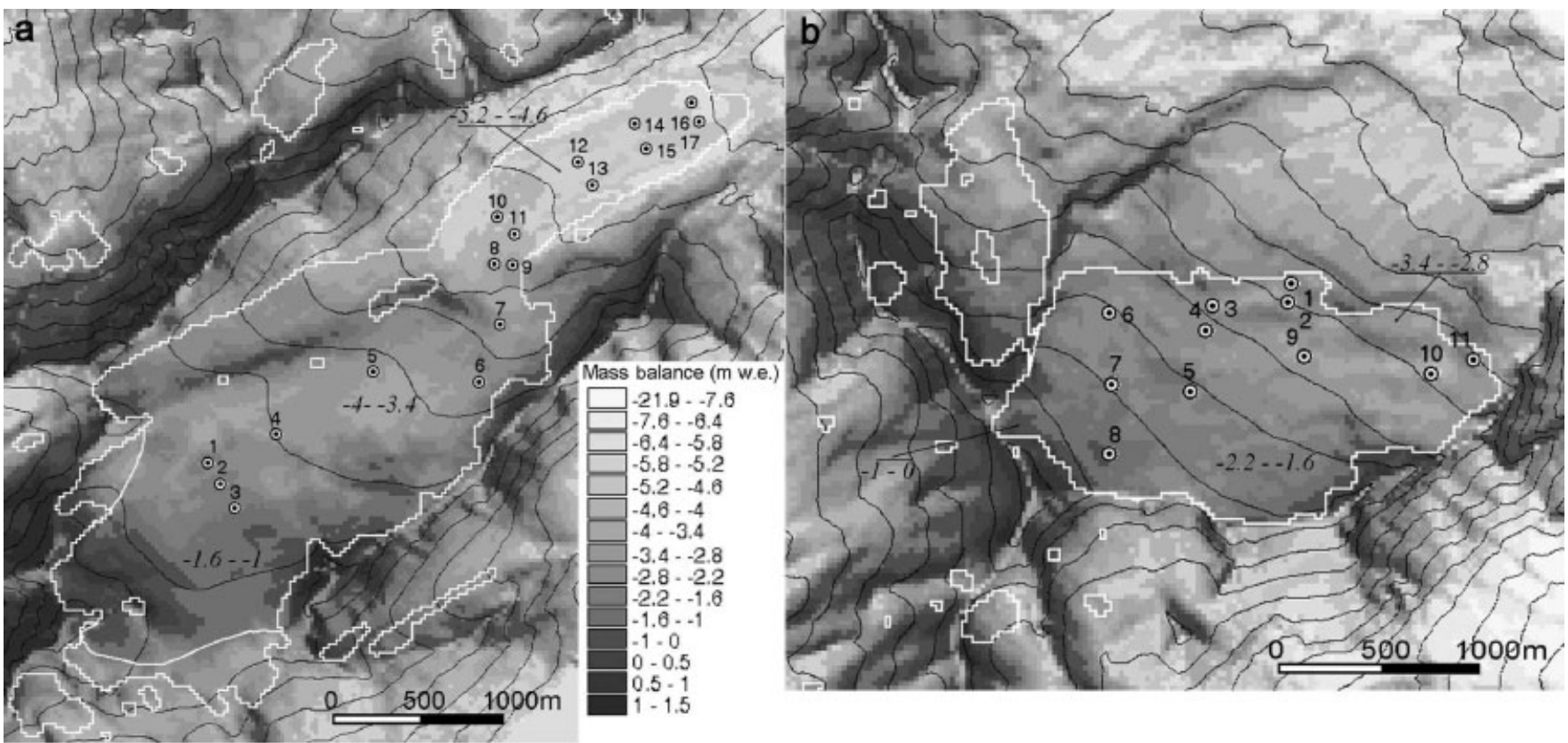

Fig. 6. Modelled mass-balance distribution for the 2002/03 balance year with stake positions (numbered), $100 \mathrm{~m}$ elevation contours from the DEM25 (black) and highlighted satellite-derived glacier areas for the year 2003: (a) for the region of Griesgletscher, and (b) for the region around Ghiacciaio del Basòdino. DEM25 reproduced by permission of Swisstopo (BA057384). The legend given in (a) is also valid for (b).

parameterizations made in the model and in view of the fact that no local tuning is applied.

A more detailed comparison of the modelled and measured values is presented in Figure $7 \mathrm{a}$, showing the massbalance profiles of both glaciers. Apart from the overall good agreement of the two curves for both glaciers, deviations are visible as well. They can be explained partly by the strong smoothing of the measured curves, which is due to the interpolation techniques applied. While the values for Griesgletscher are determined by a regression function (Funk and others, 1997), the $100 \mathrm{~m}$ mean values for Ghiacciaio del Basòdino are obtained by manual interpolation (personal communication from A. Bauder, 2005). It is difficult to say which profile is more realistic. The interpolated curves might smooth out local topographic effects (that are clearly visible in the modelled curves) and even fail under extreme conditions (Paul and others, 2005). Assuming that the measured values are correct, the model overestimates ablation in the lower parts of Griesgletscher and underestimates ablation for the upper parts, and the opposite for Ghiacciaio del Basòdino.

In order to avoid any interpolation effects, we also compared the original stake readings with the modelled values at their locations (Fig. 7b). The scatter plot displays a linear regression trend line which indicates a general overestimation of the ablation in the case of Griesgletscher by the model and an under- (over)estimation for the lower (upper) parts of Ghiacciaio del Basòdino. However, considering the large number of local effects controlling the values at individual stakes (e.g. wind drift) and the general assumptions made in our model (e.g. clouds at Robiei = clouds at Griesgletscher), the model results are satisfactory.

\section{DISCUSSION}

In case study 1 , the applied distributed mass-balance model is forced by precipitation that has been tuned with measured
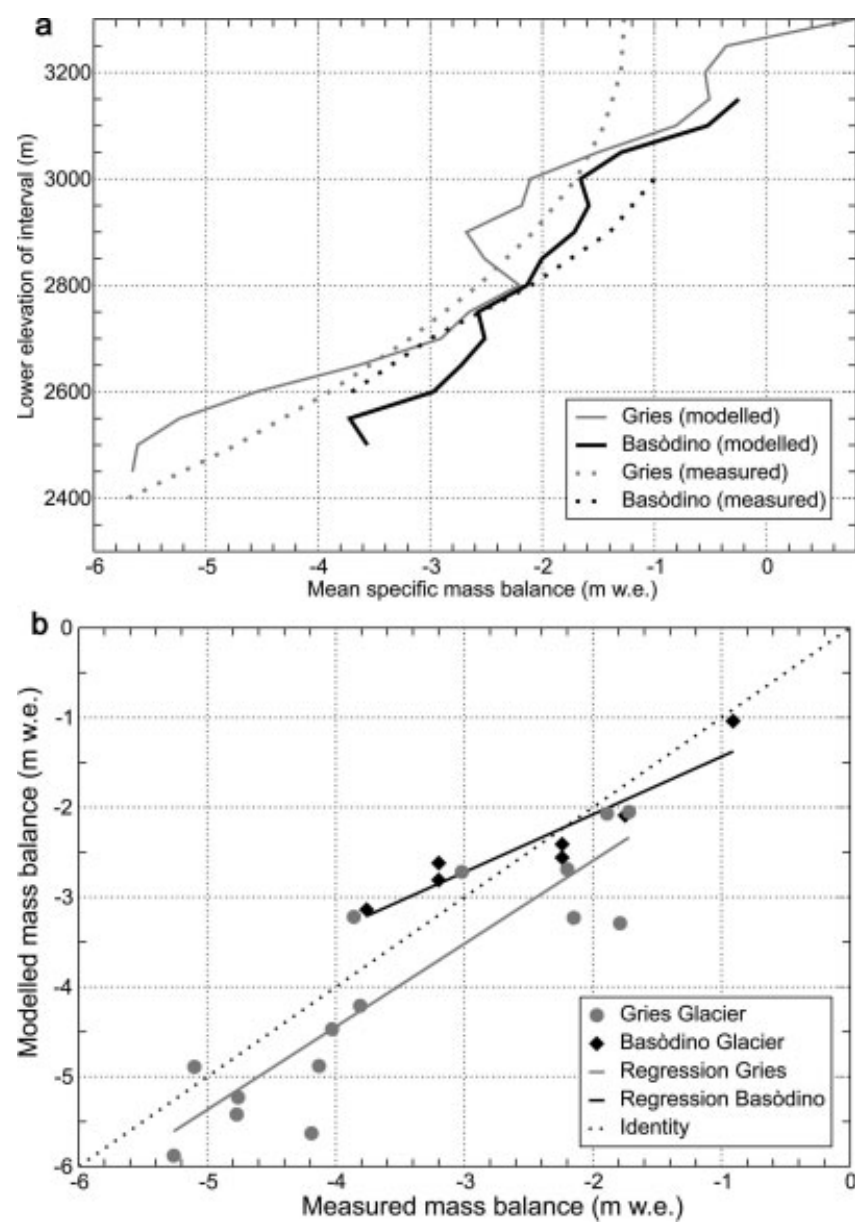

Fig. 7. (a) Modelled mass-balance profiles sampled at $50 \mathrm{~m}$ elevation bins for Griesgletscher and Ghiacciaio del Basòdino, in comparison to measurements (regression curves) in the 2002/03 balance year. (b) Scatter plot of measured vs modelled massbalance values at the stake positions (see Fig. 6). 
values of winter accumulation. Despite this tuning, a scatter of about $\pm 0.5 \mathrm{~m}$ remains for individual years at both stakes. Further improvement of the model results in individual years would primarily require the inclusion of several input parameters (e.g. cloudiness, precipitation). As the regression trend lines are very close to identity (Fig. 3b), the interannual scatter averages out in long-term mean and cumulative values (yielding very small differences after 20 years). Nevertheless, case study 1 demonstrates that simple massbalance models can provide valuable long-term results if the most important processes are treated realistically. Case study 2 illustrates the possibilities of tuning with long-term lengthchange values. Despite the simplicity of the approach, only small deviations of $\pm 0.2 \mathrm{~m}$ between long-term mean massbalance values from length-change measurements and those from a distributed mass-balance model have been obtained. Here we see a large potential of extending mass-balance series backwards in time, if the balance at the tongue is obtained from distributed modelling (accounting for local topographic effects) and glaciers with special characteristics (e.g. calving, debris cover) are excluded. Case study 3 illustrates that modelled profiles of mass balance vs elevation can reproduce the distribution patterns interpolated from measurements well if specific spatio-temporal characteristics (e.g. the low 2003 albedo values) are considered. However, the strong smoothing of the interpolated curves makes it difficult to assess which values are more accurate. For individual stakes, large deviations $( \pm 1 \mathrm{~m})$ are found in this case, which could partly be explained by deficiencies of the applied model. Nevertheless, the measured values themselves can be influenced by spatial distribution of input parameters or small-scale topography, which is difficult to assess at the spatial scale of the DEM25.

\section{CONCLUSIONS AND PERSPECTIVES}

The three case studies demonstrate the potential as well as the limitations of approaches combining point measurements with distributed mass-balance modelling. Concerning future monitoring strategies, the following conclusions can be drawn:

1. The validation and calibration of distributed massbalance models is best done by using data from sites with extensive process-oriented measurements that include winter balance determined by an adequate number of snow pits in the accumulation area. Reduced stake networks (as on Griesgletscher) and isolated index stake measurements (as on Claridenfirn) are valuable for model verification but are of limited use for increased process understanding. The applied spatial interpolation techniques have to be reproducible.

2. Long-term average mass-balance values can be obtained for (numerous) unmeasured glaciers from cumulative length-change measurements as long as there is 'active retreat' as a dynamic response (instead of 'downwasting' or 'collapse') and the glacier is not affected by special conditions (calving, debris cover, flow instability). This approach can greatly increase the representativity of the few available mass-balance measurements and help to extend the series backwards in time.

3. Further improvements of distributed mass-balance models should focus first of all on the processes taking place during the accumulation season, in particular the snow redistribution by wind, and on the spatial and temporal variability of several input parameters. The introduction of an avalanche parameterization (case study 1) as well as the use of a gridded precipitation climatology and a TM-derived albedo map (case study 3) are small steps towards the consideration of the spatial variability.

Distributed mass-balance models certainly have a much greater potential than purely statistical approaches. The following principal applications of such models can be envisaged as part of an integrated glacier-monitoring strategy:

1. local extrapolation of stake measurements (for individual glaciers)

2. distributed modelling over larger regions (including gridded datasets)

3. interpolation and extrapolation of time series (forward/ backward)

4. combination of process-based models with knowledgebased traditional methods (automated glacier lengthchange measurements from satellite data)

5. coupling with high-resolution regional climate models.

Distributed mass-balance modelling is an important tool in glacier monitoring and climate impact studies. It should become a standard component of corresponding long-term programmes.

\section{ACKNOWLEDGEMENTS}

We thank A. Bauder for providing us with the mass-balance data for Griesgletscher and Ghiacciaio del Basòdino, S. Gruber for development and implementation of the avalanche model and $\mathrm{M}$. Zemp for providing the lengthchange data. All meteorological data are kindly provided by Meteoswiss.

\section{REFERENCES}

Bundesministerium für Land- und Forstwirtschaft, Umwelt und Wasserwirtschaft (BLFUW). 2003. Hydrological atlas of Austria. Vienna, Österreichischer Kunst- und Kulturverlag.

Frei, C. and C. Schär. 1998. A precipitation climatology of the Alps from high-resolution rain-gauge observations. Int. J. Climatol., 18(8), 873-900.

Funk, M., R. Morelli and W. Stahel. 1997. Mass balance of Griesgletscher 1961-1994: different methods of determination. Z. Gletscherkd. Glazialgeol., 33(1), 41-55.

Greuell, W. and M.S. de Ruyter de Wildt. 1999. Anisotropic reflection by melting glacier ice: measurements and parameterizations in Landsat TM bands 2 and 4. Remote Sens. Environ., 70(3), 265-277.

Haeberli, W. 2004. Glaciers and ice caps: historical background and strategies of worldwide monitoring. In Bamber, J.L. and A.J. Payne, eds. Mass balance of the cryosphere. Cambridge, etc., Cambridge University Press, 559-578.

Haeberli, W. and M. Hoelzle. 1995. Application of inventory data for estimating characteristics of and regional climate-change effects on mountain glaciers: a pilot study with the European Alps. Ann. Glaciol., 21, 206-212.

Haeberli, W. and H. Holzhauser. 2003. Alpine glacier mass changes during the past two millennia. PAGES News, 11(1), 13-15. 
Haeberli, W., J. Cihlar and R.G. Barry. 2000. Glacier monitoring within the Global Climate Observing System. Ann. Glaciol., 31, 241-246.

Haeberli, W., M. Maisch and F. Paul. 2002. Mountain glaciers in global climate-related observation networks. WMO Bull., 51(1), $18-25$.

Haeberli, W., M. Zemp, R. Frauenfelder, M. Hoelzle and A. Kääb, eds. 2005. Fluctuations of glaciers 1995-2000 (Vol. VIII). Zürich, World Glacier Monitoring Service.

Herren, E., M. Hoelzle and M. Maisch. 1999. The Swiss glaciers 1995/96 and 1996/97. Zürich, Swiss Academy of Sciences. Glaciological Commission; Federal Institute of Technology. Laboratory of Hydraulics, Hydrology and Glaciology. (Glaciological Report No. 117/118.)

Hock, R. 2005. Glacier melt: a review on processes and their modelling. Progr. Phys. Geogr., 29(3), 362-391.

Hoelzle, M. and W. Haeberli. 1995. Simulating the effects of mean annual air-temperature changes on permafrost distribution and glacier size: an example from the Upper Engadin, Swiss Alps. Ann. Glaciol., 21, 399-405.

Hoelzle, M., W. Haeberli, M. Dischl and W. Peschke. 2003. Secular glacier mass balances derived from cumulative glacier length changes. Global Planet. Change, 36(4), 295-306.

Houghton, J.T. and 7 others. 2001. Climate change 2001: the scientific basis. Contribution of Working Group I to the Third Assessment Report of the Intergovernmental Panel on Climate Change. Cambridge, etc., Cambridge University Press.

Jóhannesson, T., C. Raymond and E. Waddington. 1989. Time-scale for adjustment of glaciers to changes in mass balance. J. Glaciol., 35(121), 355-369.

Klok, E.J. and J. Oerlemans. 2002. Model study of the spatial distribution of the energy and mass balance of Morteratschgletscher, Switzerland. J. Glaciol., 48(163), 505-518.

Knap, W.H., C.H. Reijmer and J. Oerlemans. 1999. Narrowband to broadband conversion of Landsat TM glacier albedos. Int. J. Remote Sens., 20(10), 2091-2110.

Machguth, H. 2003. Messung und dreidimensionale Modellierung der Massenbilanzverteilung auf Gletschern der Schweizer Alpen. (Diploma thesis, University of Zürich.)

Machguth, H., O. Eisen, F. Paul and M. Hoelzle. 2006. Strong spatial variability of snow accumulation observed with helicopter-borne GPR on two adjacent Alpine glaciers. Geophys. Res. Lett., 33 L13503. (10.1029/2006GL026576.)

Müller, H. and G. Kappenberger. 1991. Claridenfirn-Messungen 1914-1984. Zürcher Geogr. Schr. 40.
Nye, J.F. 1960. The response of glaciers and ice-sheets to seasonal and climatic changes. Proc. R. Soc. London, Ser. A, 256(1287), 559-584.

Oerlemans, J. 1992. Climate sensitivity of glaciers in southern Norway: application of an energy-balance model to Nigardsbreen, Hellstugubreen and Alfotbreen. J. Glaciol., 38(129), 223-232.

Oerlemans, J. 1993. A model for the surface balance of ice masses: part I. Alpine glaciers. Z. Gletscherkd. Glazialgeol., 27-28, 1991/1992, 163-83.

Oerlemans, J. 2001. Glaciers and climate change. Lisse, etc., A.A. Balkema.

Oerlemans, J. and 10 others. 1998. Modelling the response of glaciers to climate warming. Climate Dyn., 14(4), 267-274.

Paul, F., A. Kääb, M. Maisch, T. Kellenberger and W. Haeberli. 2002. The new remote-sensing-derived Swiss glacier inventory. I. Methods. Ann. Glaciol., 34, 355-361.

Paul, F., A. Kääb, M. Maisch, T. Kellenberger and W. Haeberli. 2004. Rapid disintegration of Alpine glaciers observed with satellite data. Geophys. Res. Lett., 31(21), L21402. (10.1029/ 2004GL020816.)

Paul, F., H. Machguth and A. Kääb. 2005. On the impact of glacier albedo under conditions of extreme glacier melt: the summer of 2003 in the Alps. EARSel eProc., 4(2), 139-149.

Paul, F., H. Machguth, M. Hoelzle, N. Salzmann and W. Haeberli. In press. Alpine-wide distributed glacier mass balance modelling: a tool for assessing future glacier change? In Orlove, B., B. Luckman and E. Wiegandt, eds. The darkening peaks: glacial retreat in scientific and social context. Berkeley, CA, etc., University of California Press.

Quinn, P., K. Beven, P. Chevallier and O. Planchon. 1991. The prediction of hillslope flow paths for distributed hydrological modeling using digital terrain models. Hydrol. Process., 5, 59-80.

Schär, C. and 6 others. 2004. The role of increasing temperature variability in European summer heatwaves. Nature, 427(6972), 332-336.

Schwarb, M., C. Daly, C. Frei and C. Schär. 2001. Mean annual precipitation throughout the European Alps, 1971-1990. In Hydrologic atlas of Switzerland. Bern, National Hydrologic Service, plate 2.6.

Schweizer Akademie der Naturwissenschaften. Gletscherkommission (SCNAT). 1992. Die Gletscher der Schweizer Alpen - 1983/ 84 und 1984/85, 105. und 106. Bericht. Zürich, Eidgenössische Technische Hochschule. Versuchsanstalt für Wasserbau, Hydrologie und Glaziologie.

Wilson, J.P. and J.C. Gallant, eds. 2000. Terrain analysis: principles and applications. New York, etc., Wiley. 